\title{
Pengaruh Muka Air Waduk Saat Pengisian Awal Terhadap Deformasi dan Rekahan pada Tubuh Bendungan (Studi Kasus: Bendungan Titab)
}

\author{
I Made Adnyana Nala ${ }^{1 *}$, Sri Sangkawati ${ }^{2}$, Thomas Triadi Putranto ${ }^{3}$ \\ ${ }^{1}$ Balai Wilayah Sungai Bali-Penida, Kementerian Pekerjaan Umum dan Perumahan Rakyat \\ ${ }^{2}$ Departemen Teknik Sipil, Fakultas Teknik, Universitas Diponegoro, Semarang \\ ${ }^{3}$ Departemen Teknik Geologi, Fakultas Teknik, Universitas Diponegoro, Semarang
}

\begin{abstract}
Abstrak
Pembangunan bendungan berfungsi untuk mengurangi intensitas banjir, serta dapat dimanfaatkan juga untuk kebutuhan air baku, pengairan, pariwisata, pembangkit tenaga listrik, serta yang lain. Selain memiliki manfaat yang sangat besar, bendungan juga memiliki potensi bahaya di dalamnya, apalagi jika tidak didukung dengan pengelolaan dan pemantauan yang baik. Pada saat pengisian awal waduk, terdapat temuan rekahan memanjang pada puncak Bendungan Titab pada tanggal 3 Februari 2016 dengan lebar $\pm 10-15 \mathrm{~cm}$ panjang $\pm 50 \mathrm{~m}$ kedalaman $\pm 50 \mathrm{~cm}$. Rekahan tersebut diperkirakan akibat perbedaan deformasi yang terjadi pada daerah hulu, tengah dan hilir. Penelitian ini bertujuan untuk menganalisis pengaruh muka air waduk terhadap deformasi pada tubuh bendungan yang berdampak terjadinya rekahan pada puncak bendungan. Metode yang digunakan adalah dengan mengiterpretasikan data pembacaan patok geser dan inclinometer disandingkan dengan elevasi muka air waduk. Hasil analisis menunjukkan nilai deformasi vertikal pada puncak bendungan bagian hilir lebih besar dari nilai deformasi vertikal puncak bendungan bagian hulu pada patok 1, 2, dan 3, sedangkan nilai deformasi bagian hulu lebih besar dari nilai deformasi bagian hilir pada patok 4 dan 5 . Deformasi horizontal daerah hulu mengarah ke hulu sedangkan deformasi horizontal daerah hilir bergerak ke hilir. Dapat disimpulkan bahwa deformasi pada puncak Bendungan Titab terjadi akibat beban air waduk saat pengisian awal waduk dan rekahan memanjang pada puncak bendungan disebabkan karena perbedaan nilai deformasi vertikal antara hulu dan hilir dan arah deformasi horizontal pada puncak bendungan.
\end{abstract}

Kata kunci: bendungan; deformasi; rekahan; pengisian awal waduk

\begin{abstract}
The construction of the dam serves to reduce the intensity of flooding, and can also be used for raw water, irrigation, tourism, hydro power, and others. Apart from having great benefits, dams also have potential hazards in them, especially if they are not supported by good management and monitoring. At the time of initial filling of the reservoir, there were findings of longitudinal fractures at the crest of the Titab Dam on February 3rd, 2016 with a width of $\pm 10-15 \mathrm{~cm}$ long $\pm 50 \mathrm{~m}$ depth of $\pm 50 \mathrm{~cm}$. These fractures are thought to be due to differences in deformation that occur in the upstream, middle and downstream areas. This study aims to analyze the effect of reservoir water level on deformation of the dam which has an impact on fractures at the crest dam. The method used is to interpret the reading of the surface monument and inclinometer readings compared to the reservoir water level elevation. The results of the analysis show that the value of vertical deformation at the crest of the downstream dam is greater than upstream at stakes 1,2, and 3, while the value of the deformation of the upstream is greater than downstream at stakes 4 and 5. Horizontal deformation the upstream area leads upstream while the horizontal deformation of the downstream area moves downstream. It can be concluded that the deformation at the crest of the Titab Dam occurs due to the reservoir water load during the initial filling and the longitudinal fracture at the crest dam is caused by the difference in the value of vertical
\end{abstract}

\footnotetext{
*) Korespondensi: adnyananala@gmail.com

Diajukan : 19 Juli 2021

Diterima : 30 November 2021

Diterbitkan : 3 Desember 2021
} 
deformation between upstream and downstream and the direction of horizontal deformation at the crest dam.

Keywords: Dam, deformation, fractures, initial filling.

\section{PENDAHULUAN}

Bendungan merupakan bangunan air untuk menahan laju aliran air secara alamiah ataupun buatan yang kemudian akan ditampung atau disimpan menjadi waduk. Pembangunan bendungan berfungsi untuk mengurangi intensitas banjir, serta dapat dimanfaatkan juga kebutuhan air baku, pengairan, pariwisata, pembangkit tenaga listrik, serta yang lain. Selain memiliki manfaat yang sangat besar, bendungan juga memiliki potensi bahaya di dalamnya, apalagi jika tidak didukung dengan pengelolaan dan pemantauan yang baik. Bendungan yang runtuh dapat menimbulkan bencana besar yang dapat mengakibatkan kerusakan lingkungan, harta benda bahkan korban jiwa di daerah hilir. Kegagalan bendungan akan mengakibatkan banjir yang tidak terkendali sehingga dapat merugikan seperti kematian dan kerugian ekonomi.

Gejala bahaya pada bendungan dapat dideteksi dengan melakukan pemantauan secara rutin. Pemantauan perilaku bendungan tipe urugan membutuhkam alat instrumentasi geoteknik. Peralatan instrumentasi geoteknik tersebut akan memberikan informasi terjadinya deformasi baik vertikal maupun horizontal, rembesan air, tekanan pori, dan lain-lain. Pemantauan instrumentasi ini diperlukan pada saat pelaksanaan konstruksi, pengisian pertama dan selama bendungan tersebut beroperasi. Hal ini ditujukan untuk mengetahui dan mendeteksi secara dini apabila terjadi suatu tanda-tanda yang tidak normal yang berkaitan dengan keamanan bendungan (Central Water Commission, 2018).

Salah satu masalah krusial pada bendungan urugan adalah pada saat awal pengisian waduk. Deformasi yang terjadi pada pengisian awal waduk sangat kompleks. Hal-hal yang dapat mempengaruhi adalah tekanan air pada inti bagian hulu dapat meningkatkan tegangan lateral sehingga menjadi beban pada bendungan, pengaruh tekanan air pada hulu pondasi, penurunan tegangan efektif material timbunan, dan penurunan parameter kuat geser, modulus elastisitas material timbunan sehingga terjadi pelapukan yang menyebabkan terjadinya penurunan (Rashidi dan Haeri, 2017).

Won dan Kim (2008), pada penelitian yang dilakukan pada 27 bendungan tipe urugan batu dengan permukaan beton (Concrete Face Rock Fill Dams) menyatakan pada saat pengisian waduk pertama sangat berpengaruh pada penurunan dan deformasi pada puncak bendungan. Kebanyakan deformasi terjadi pada bagian hulu. Besarnya penurunan pada puncak bendungan pasca konstruksi dalam jangka waktu yang lama sama dengan deformasi pada bagian hulu, dan terdapat kecenderungan bahwa penurunan puncak lebih besar dari deformasi pada bagian hulu pada bendungan dengan ketinggian kurang dari $100 \mathrm{~m}$.

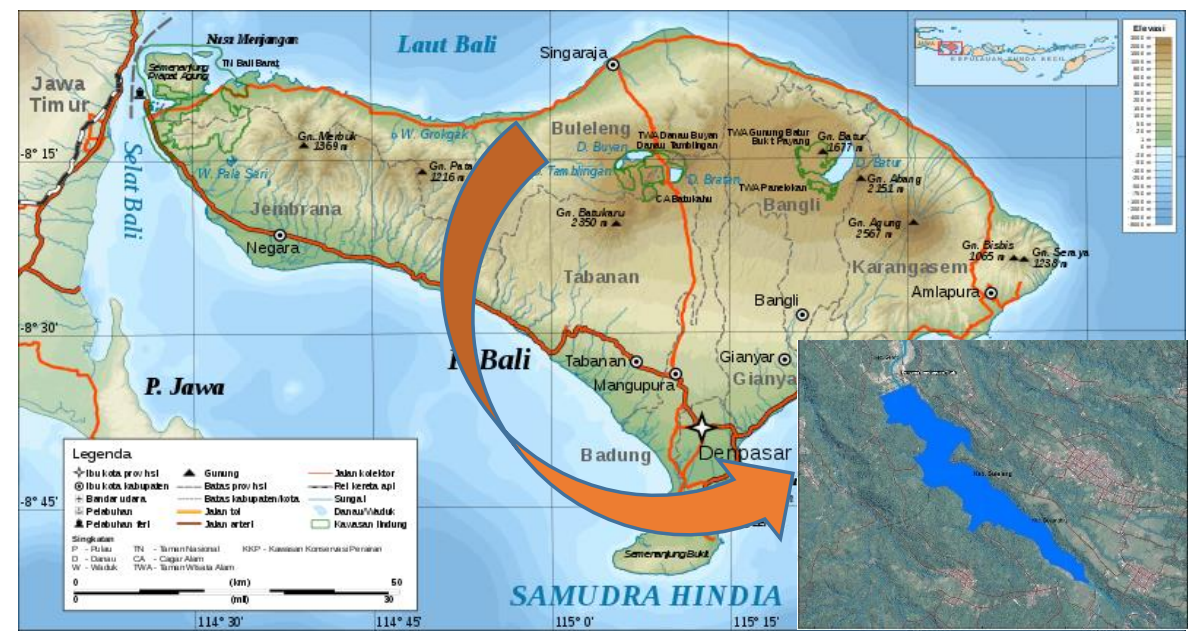

Gambar 1. Peta lokasi Bendungan Titab (BWS Bali-Penida, 2015) 
Masalah pada tahap pengisian awal juga terjadi di Bendungan Titab. Bendungan ini dibangun pada tahun 2009-2015 terletak pada aliran Sungai Saba di Kabupaten Buleleng Provinsi Bali. Bendungan Titab merupakan bendungan tipe urugan batu random dengan inti tegak dengan tinggi 77,80 meter dari dasar galian. Puncak bendungan berada pada elevasi $164,00 \mathrm{~m}$ sepanjang $210 \mathrm{~m}$ dan lebar $12 \mathrm{~m}$. Manfaat bendungan untuk mengairi irigasi seluas 1.794 ha, air baku sebesar $0,35 \mathrm{~m} 3 / \mathrm{dt}$, dan PLTA (MWH) sebesar 1,5 MW. Lokasi Bendungan Titab dapat dilihat pada Gambar 1.

Dalam Laporan Hasil Diskusi Teknis KKB Pembahasan Kondisi Bendungan Titab, Kabupaten Buleleng, Provinsi Bali tanggal 7 April 2016 disebutkan bahwa pengisian pertama waduk dilakukan pada tanggal 5 Januari 2016, dan pada tanggal 15 Januari 2016 elevasi muka air waduk sudah mencapai $\pm 133,5$ m sedangkan elevasi mulut intake pada elevasi $\pm 130,8 \mathrm{~m}$ artinya air waduk sudah masuk melalui mulut intake. Pada proses pengisian pertama waduk, terdapat beberapa kejadian yang tidak wajar diantaranya, tanggal 16 Januari 2016 terdapat kejadian bunyi dentuman yang cukup keras sehingga terjadi semburan air pada mulut intake setinggai $\pm 40 \mathrm{~m}$ yang menyebabkan penutup menara intake terangkat dan pada tanggal 18 Januari 2016 kembali terjadi semburan air dari menara intake namun lebih kecil. Tanggal 3 Februari 2016 terdapat rekahan memanjang pada puncak bendungan bagian hulu dengan lebar \pm 10 $15 \mathrm{~cm}$ panjang $\pm 50 \mathrm{~m}$ kedalaman $\pm 50 \mathrm{~cm}$ dan dilaporkan kembali pada tanggal 23 Februari 2016 terjadi penambahan lebar rekahan menjadi $\pm 20 \mathrm{~cm}$. Kondisi retakan memanjang pada puncak bendungan dapat dilihat pada Gambar 2 .

Berdasarkan beberapa kejadian tersebut, pihak KKB menyarankan untuk melakukan pengosongan waduk dan segera melakukan langkah-langkah perbaikan. Pengosongan waduk dilakukan pada tanggal 15 Maret 2016 dari elevasi muka air waduk $\pm 131,7 \mathrm{~m}$ sampai dengan tanggal 13 Agustus 2016 pada elevasi \pm 112,415 $\mathrm{m}$. Setelah perbaikan dinding conduit selesai, pada tanggal 29 November 2017 pengisian waduk kembali dilakukan.

Indrawan dkk. (2015), melakukan analisis perilaku Bendungan Sutami akibat gempa dengan mempertimbangkan retakan pada puncak bendungan. Analisis tersebut dilakukan dengan pemodelan numerik dengan analisis statis dan dinamis untuk mengetahui penyebab dan mekanisme retakan. Hasil analisis statis menunjukkan bahwa puncak bendungan cenderung mengalami penurunan ke arah hulu, besar penurunan puncak bagian hulu lebih besar dibandingkan bagian hilir. Berdasarkan analisis dinamis akibat gempa SEE (Safety Evaluation Earthquake) kemugkinan terjadinya masalah stabilitas pada lereng hilir dan hulu sangat kecil, sehingga kecil kemungkinan terjadi permasalahan stabilitas lereng. Disimpulkan Bendungan Sutami aman terhadap skenario gempa SEE.

Setiap bangunan yang mendapatkan tekanan secara terus menerus akan berpotensi mengalami perubahan posisi, dimensi maupun bentuk. Salah satunya adalah bendungan, dimana beban yang diterima oleh bendungan selain beban sendiri adalah beban berupa beban air pada waduk. Akibat tekanan air tersebut, memungkinkan tubuh bendungan akan mengalami deformasi (Purwoko dkk., 2017).

Deformasi pada tubuh bendungan sangat dipengaruhi oleh beban air waduk pada saat pengisian awal waduk. Rekahan pada puncak bendungan lebih disebabkan karena perbedaan deformasi yang terjadi di daerah hulu, tengah, dan

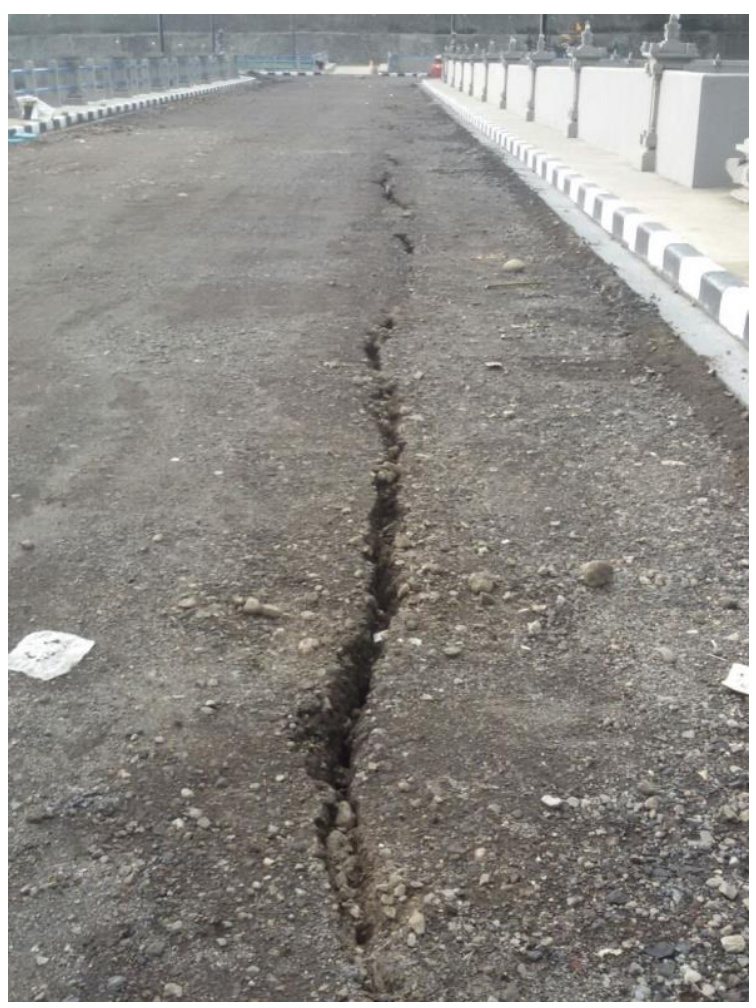

Gambar 2. Kondisi rekahan memanjang pada puncak Bendungan Titab (BWS Bali-Penida, 2016) 
hilir bendungan. Nilai deformasi pada sisi hulu lebih besar dari pada bagian hilirnya, sehingga rekahan yang terjadi pada puncak Bendungan Titab ditemukan memanjang pada daerah hulu (Wang, 2007; Won dan Kim, 2008; Zhou dkk., 2020).

Penelitian terhadap Bendungan Titab terkait stabilitas lereng pada bagian hulu menunjukkan angka keamanan di atas 1,2 dengan pemasangan Geotekstil pada tubuh bendungan. Apabila tidak memakai geotekstil angka keamanan tidak mencapai 1,2. Lereng dikatakan aman apabila tidak dibebani air (Putra dkk., 2019).

Dalam penelitian yang dilakukan oleh (Anggara dkk., 2021) terhadap analisis rembesan pada Bendungan Titab menunjukkan nilai yang cukup tinggi yaitu rata-rata sebesar 4,740 $\mathrm{lt} / \mathrm{min} / \mathrm{m}$ dari nilai batas maksimum sebesar 0,56 $\mathrm{lt} / \mathrm{min} / \mathrm{m}$. Nilai index rembesan juga menunjukkan nilai (Qi) lebih besar dari 1 yaitu sebesar 5,73 pada tahun 2016 dan 6,70 pada tahun 2017. Faktor keamanan terhadap bahaya piping menunjukkan nilai yang dapat ditoleransi yaitu $\mathrm{FK}_{\text {piping }}$ dengan nilai 8,39>4.

Penelitian ini bertujuan untuk menganalisis pengaruh muka air waduk pada saat pengisian awal waduk terhadap deformasi yang terjadi pada tubuh bendungan sehingga berdampak pada rekahan pada puncak bendungan dengan menginterpretasikan data pembacaan instrumentasi patok geser dan inclinometer yang terpasang pada tubuh bendungan.

\section{METODOLOGI}

Dalam analisis deformasi pada Bendungan Titab, data instrumentasi yang digunakan merupakan data pemantauan pengelola Bendungan Titab yaitu Balai Wilayah Sungai Bali-Penida. Data patok adalah data pembacaan awal (initial reading) pada bulan November 2015 sampai dengan Bulan Agustus 2016, dimana pengisian awal waduk dilaksanakan pada awal Bulan Januari 2016 dan dilakukan pengosongan waduk pada Bulan Agustus 2016. Tahapan analisis dapat dilihat pada Gambar 2.

Jumlah patok geser yang terpasang pada Bendungan Titab sebanyak 27 buah yang terdiri dari 10 buah pada puncak bendungan dimana 5 buah pada puncak bagian hulu dan 5 buah pada puncak bagian hilir. 17 buah pada bagian lereng dimana 5 buah pada lereng hulu dan 12 buah pada lereng hilir. Penempatan patok geser secara detail dapat dilihat pada Gambar 4. Pembacaan koordinat awal (initial reading) dapat dilihat pada Tabel 1 dan Tabel 2.

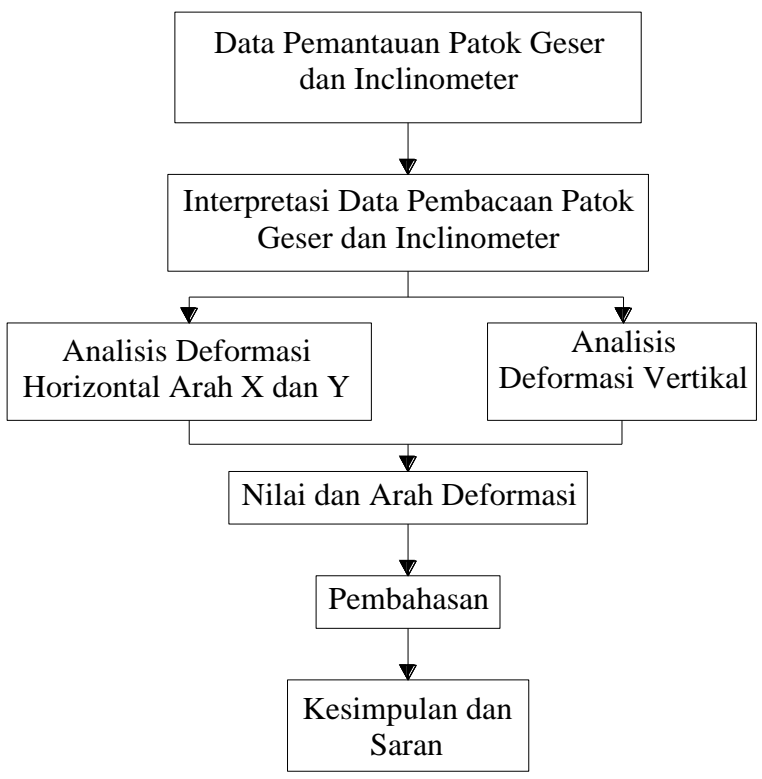

Gambar 3. Tahapan analisis

Tabel 1. Koordinat awal patok geser pada lereng Bendungan Titab

\begin{tabular}{|c|c|c|c|}
\hline \multirow{2}{*}{ Patok Geser } & \multicolumn{3}{|c|}{ Koordinat } \\
\hline & $\mathrm{X}$ & $\mathrm{Y}$ & $\mathrm{Z}$ \\
\hline \multicolumn{4}{|c|}{ Lereng Bagian Hulu } \\
\hline SSU.1 & 273330.799 & 9088038.458 & 157.785 \\
\hline SSU.2 & 273370.645 & 9088042.200 & 157.645 \\
\hline SSU.3 & 273410.432 & 9088045.934 & 157.787 \\
\hline SSU.4 & 273450.175 & $9088049.503^{\prime \prime}$ & 157.872 \\
\hline SSU.5 & 273489.566 & 9088053.348 & 157.787 \\
\hline \multicolumn{4}{|c|}{ Lereng Bagian Hilir } \\
\hline SSD. 1 & 273327.597 & 9088076.784 & 156.111 \\
\hline SSD. 2 & 273367.046 & 9088080.534 & 155.812 \\
\hline SSD. 3 & 273406.816 & 9088084.242 & 155.947 \\
\hline SSD.4 & 273446.650 & 9088087.975 & 155.920 \\
\hline SSD.5 & 273486.429 & 9088091.738 & 155.953 \\
\hline SSD.6 & 273364.170 & 9088110.815 & 140.552 \\
\hline SSD.7 & 273403.995 & 9088114.534 & 140.496 \\
\hline SSD. 8 & 273443.805 & 9088118.322 & 140.599 \\
\hline SSD.9 & 273483.488 & 9088122.057 & 140.589 \\
\hline SSD.1C & 273401.169 & 9088144.441 & 125.967 \\
\hline SSD.11 & 273441.178 & 9088148.086 & 125.462 \\
\hline SSD.12 & 273480.879 & 9088151.927 & 125.576 \\
\hline
\end{tabular}




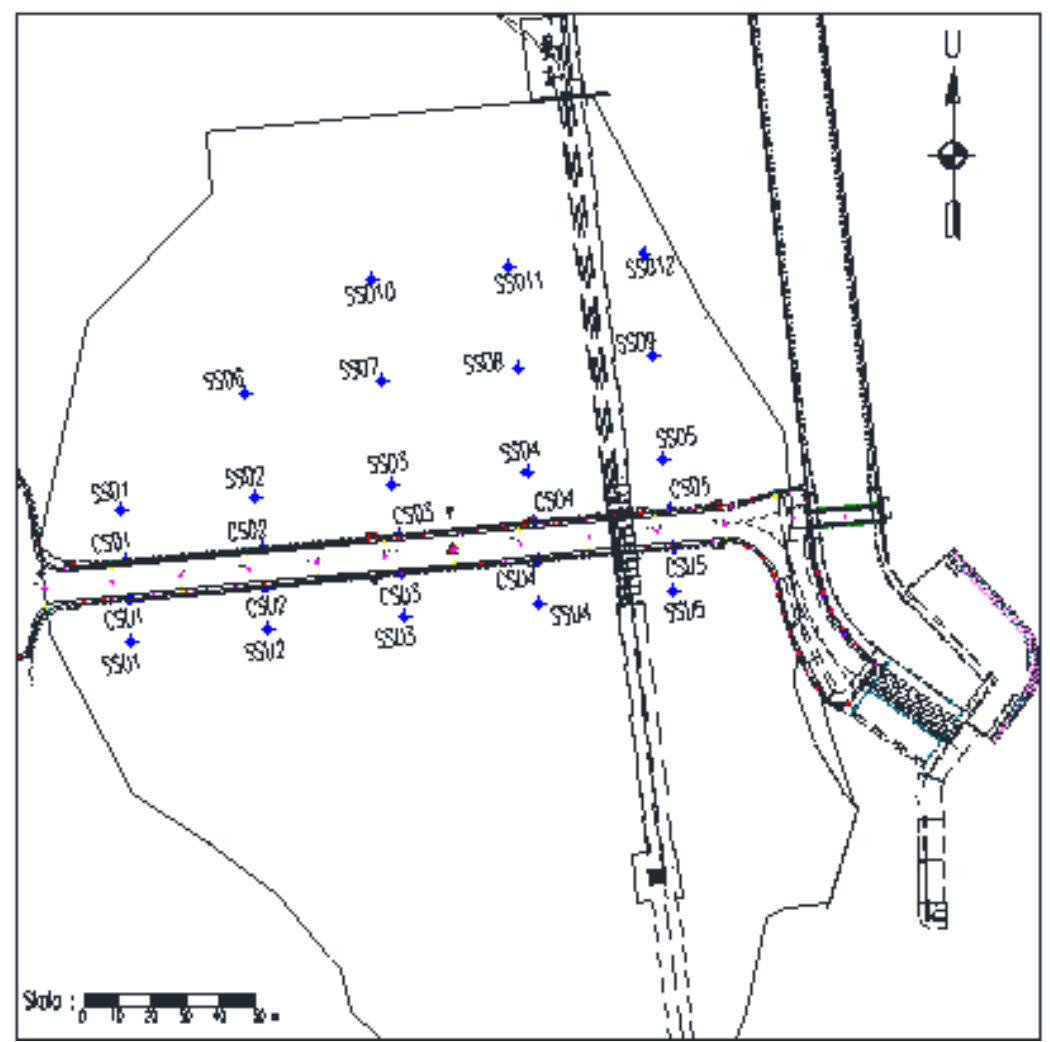

Gambar 4. Denah pemasangan instrumentasi patok geser pada Bendungan Titab (BWS Bali-Penida, 2015)

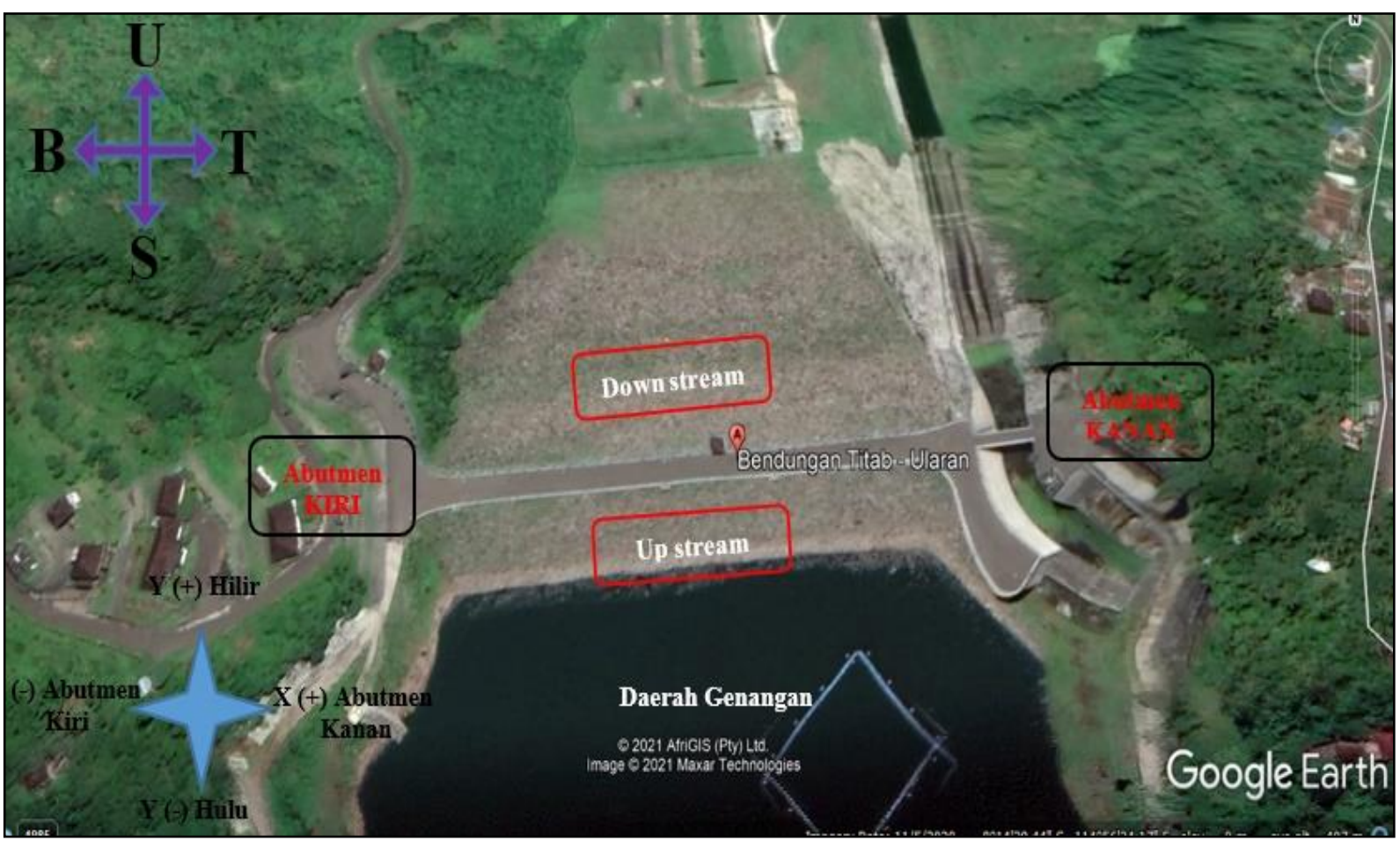

Gambar 5. Petunjuk arah pergerakan patok geser (Google Earth, 2021) 
Data hasil pembacaan patok geser berupa koordinat titik UTM dengan sumbu X (arah Timur-Barat), sumbu Y (arah Utara-Selatan) dan sumbu Z (arah Vertikal). Petunjuk arah pergerakan patok geser dapat dilihat pada Gambar 5. Pembacaan untuk nilai $\mathrm{Y}(+)$ menunjukkan pergerakan ke arah hilir dan nilai

Tabel 2. Koordinat awal patok geser pada puncak Bendungan Titab

\begin{tabular}{|c|c|c|c|}
\hline \multirow{2}{*}{ Patok Geser } & \multicolumn{3}{|c|}{ Koordinat } \\
\hline & $X$ & $\mathrm{Y}$ & $\mathrm{Z}$ \\
\hline \multicolumn{4}{|c|}{ Puncak Bagian Hulu } \\
\hline CSU.1 & 273330.552 & 9088050.686 & 162.441 \\
\hline CSU.2 & 273370.144 & 9088054.368 & 163.374 \\
\hline CSU.3 & 273409.878 & 9088058.165 & 163.605 \\
\hline CSU.4 & 273450.010 & 9088061.911 & 163.528 \\
\hline CSU.5 & 273489.759 & 9088065.646 & 162.791 \\
\hline \multicolumn{4}{|c|}{ Puncak Bagian Hilir } \\
\hline CSD. 1 & 273329.394 & 9088062.422 & 162.437 \\
\hline CSD. 2 & 273369.121 & 9088066.103 & 163.179 \\
\hline CSD. 3 & 273408.959 & 9088069.790 & 163.629 \\
\hline CSD.4 & 273448.883 & 9088073.579 & 163.520 \\
\hline CSD.5 & 273488.252 & 9088077.334 & 162.820 \\
\hline
\end{tabular}

Y(-) menunjukkan pergerakan ke arah hulu. Pembacaan nilai $\mathrm{X}(+)$ menunjukkan pergerakan longitudinal ke arah Timur (abutmen Kanan) sedangkan pembacaan nilai $\mathrm{X}(-)$ menunjukkan pergerakan longitudinal ke arah Barat (abutmen Kiri). Hasil pembacaan koordinat patok geser dianalisis dan dituangkan ke dalam bentuk grafik untuk mengetahui nilai dan arah deformasi yang terjadi pada masing-masing titik patok geser.

\section{HASIL}

Deformasi Vertikal

Deformasi vertikal pada puncak bendungan dianalisis menggunakan data pembacaan patok geser pada puncak bendungan bagian hulu dengan kode CSU dan bagian hilir dengan kode CSD. Gambar 6 menunjukkan deformasi vertikal pada puncak bendungan bagian hulu dan Gambar 7 menunjukkan deformasi vertikal pada puncak bagian hilir bendungan berdasarkan waktu. Deformasi vertikal pada puncak bendungan bagian hulu pada patok CSU 4 dan CSU 3 lebih besar dibandingkan dengan patok yang lainnya.

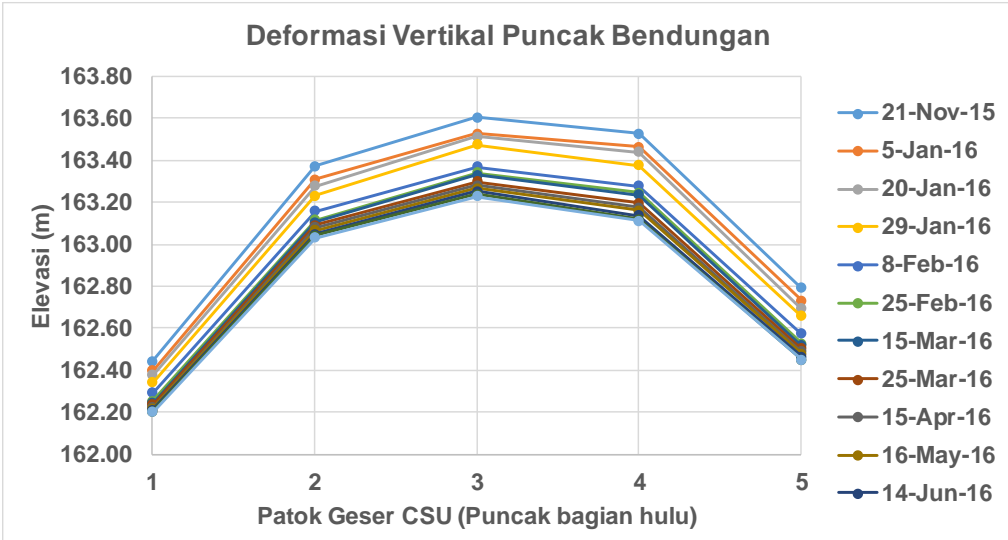

Gambar 6. Grafik deformasi vertikal pada puncak bendungan bagian hulu.

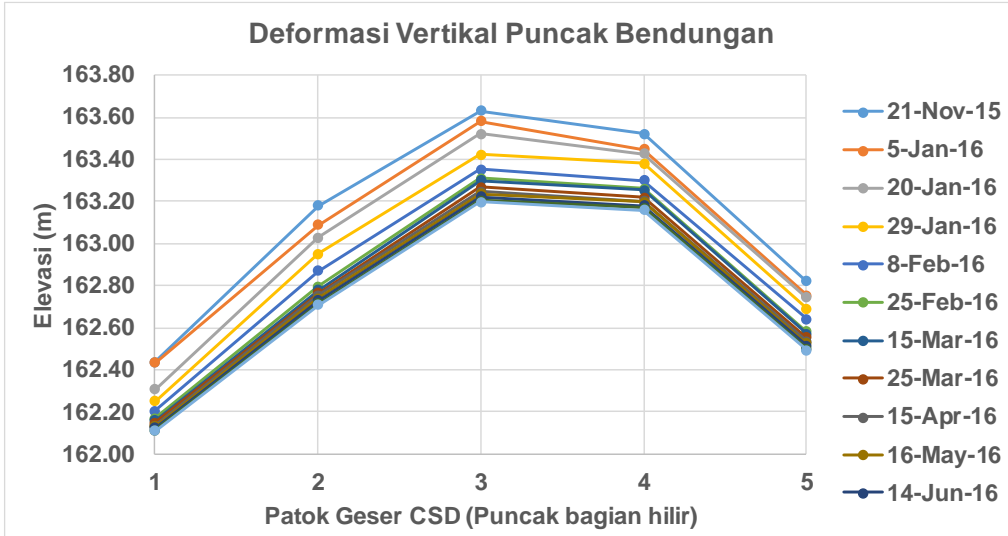

Gambar 7. Grafik deformasi vertikal pada puncak bendungan bagian hilir 
Berbeda dengan deformasi puncak bendungan bagian hilir dimana patok CSD 2 dan CSD 3 lebih besar dari pada patok yang lainnya. Namun dari Gambar 6 dan Gambar 7 menunjukkan bahwa deformasi vertikal yang paling besar terjadi pada tengah-tengah bentang yaitu patok CSD2 dan CSD3. Perbandingan nilai deformasi vertikal pada puncak bendungan bagian hulu dan hilir diketahui dengan cara membandingkan patok CSU3 dan CSD3 berdasarkan ketinggian muka air waduk dapat dilihat pada Gambar 8 .

Berdasarkan Gambar 8, deformasi vertikal pada puncak bendungan semakin bertambah besar mengikuti peningkatan elevasi muka air waduk pada pengisian awal waduk. Hal ini menunjukkan bahwa pembebanan akibat air waduk mempengaruhi nilai deformasi vertikal pada tubuh bendungan. Nilai deformasi vertikal pada puncak bendungan bagian hilir lebih besar dibandingkan dengan nilai deformasi vertikal pada puncak bendungan bagian hulu. Untuk lebih jelas nilai deformasi vertikal pada puncak bendungan bagian hulu dan hilir dapat dilihat pada Tabel 3.

Berdasarkan Tabel 3, nilai deformasi vertikal terbesar selama pengisian awal waduk terletak pada patok geser dengan kode CSD2 dengan nilai sebesar 0,471 $\mathrm{m}$ atau 47,1 $\mathrm{cm}$ dan CSD3 dengan nilai sebesar $0,432 \mathrm{~m}$ atau $43,2 \mathrm{~cm}$ terhitung sejak pembacaan awal pada tanggal 21 November 2016 sampai dengan tanggal 15 Agustus 2016. Kemungkinan nilai tersebut akan bertambah seiring dengan waktu operasi waduk.

\section{Deformasi Horizontal}

Analisis deformasi horizontal dilakukan dengan menggunakan data patok geser yang terpasang pada puncak bendungan yaitu patok geser dengan kode CSU untuk bagian hulu dan CSD pada bagian hilir. Deformasi horizontal yang terjadi pada puncak bendungan dapat dilihat pada Gambar 8 sampai dengan Gambar 12 berturutturut dari abutmen kiri ke abutmen kanan.

Gambar 9 menunjukkan deformasi horizontal pada puncak bendungan bagian abutmen kiri berdasarkan patok CSU1 (hulu) dan CSD1 (hilir). Pergerakan yang terjadi adalah puncak bendungan bagian hulu bergerak kehulu dan mengarah ke kanan sedangkan pergerakan puncak bendungan bagian hilir bergerak ke hilir dan kekanan (menuju lembah). Deformasi yang terjadi sebesar $0,2 \mathrm{~m}$ pada tanggal 5 Januari 2016 dan berkurang menjadi $0,189 \mathrm{~m}$ pada tanggal 25 Februari 2016. Nilai deformasi patok CSU1 dan CSD1 dapat dilihat pada Tabel 4.

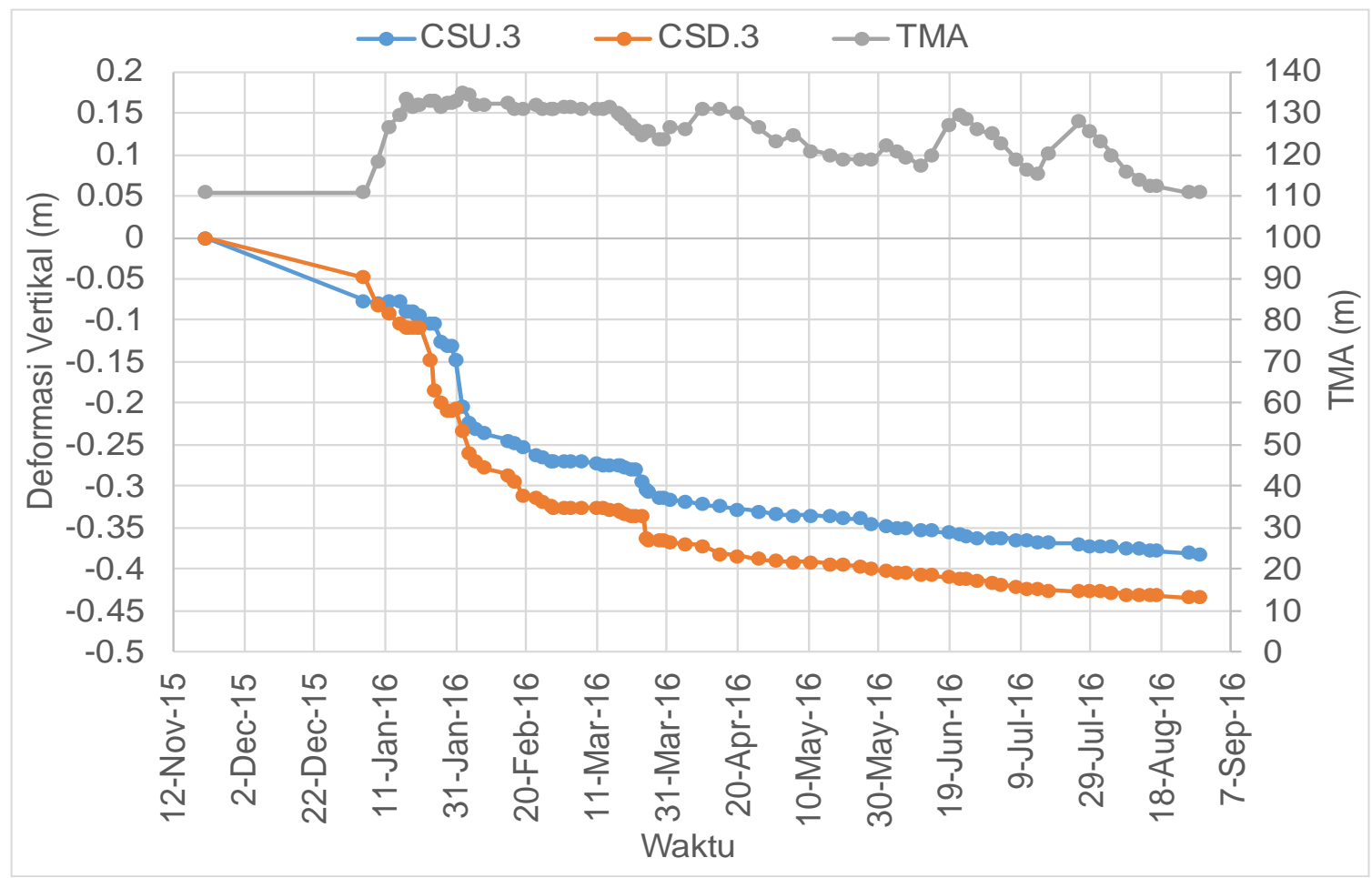

Gambar 8. Grafik nilai deformasi vertikal pada puncak bendungan terhadap muka air waduk 
Tabel 3. Nilai deformasi vertikal pada puncak bendungan

\begin{tabular}{|c|c|c|c|c|c|c|c|c|c|c|c|c|c|c|c|c|c|c|c|c|c|}
\hline \multirow{2}{*}{$\begin{array}{c}\text { Tanggal } \\
\text { Pembacaan }\end{array}$} & \multirow[b]{2}{*}{ TMA } & \multicolumn{2}{|c|}{ CSU1 } & \multicolumn{2}{|c|}{ CSD1 } & \multicolumn{2}{|c|}{ CSU2 } & \multicolumn{2}{|c|}{ CSD2 } & \multicolumn{2}{|c|}{ CSU3 } & \multicolumn{2}{|c|}{ CSD3 } & \multicolumn{2}{|c|}{ CSU4 } & \multicolumn{2}{|c|}{ CSD4 } & \multicolumn{2}{|c|}{ CSU5 } & \multicolumn{2}{|c|}{ CSD5 } \\
\hline & & $\mathrm{Z}$ & $\Delta \mathrm{Z}$ & $\mathrm{Z}$ & $\Delta \mathrm{Z}$ & $\mathrm{Z}$ & $\Delta \mathrm{Z}$ & $\mathrm{Z}$ & $\Delta \mathrm{Z}$ & $\mathrm{Z}$ & $\Delta \mathrm{Z}$ & $\mathrm{Z}$ & $\Delta \mathrm{Z}$ & $\mathrm{Z}$ & $\Delta \mathrm{Z}$ & Z & $\Delta \mathrm{Z}$ & Z & $\Delta \mathrm{Z}$ & $\mathrm{Z}$ & $\Delta \mathrm{Z}$ \\
\hline 21-Nov-15 & & 162.441 & 0 & 162.437 & & 163.374 & & 163.179 & & 163.605 & & 163.629 & & 163.528 & & 163.52 & & 162.791 & & 162.82 & \\
\hline 5-Jan-16 & 110.932 & 162.398 & -0.043 & 162.432 & -0.005 & 163.308 & -0.066 & 163.089 & -0.090 & 163.529 & -0.076 & 163.581 & -0.048 & 163.465 & -0.063 & 163.448 & -0.072 & 162.731 & -0.060 & 162.752 & -0.068 \\
\hline 29-Jan-16 & 132.344 & 162.341 & -0.1 & 162.249 & -0.188 & 163.233 & -0.141 & 162.950 & -0.229 & 163.474 & -0.131 & 163.421 & -0.208 & 163.376 & -0.152 & 163.380 & -0.140 & 162.658 & -0.133 & 162.689 & -0.131 \\
\hline 8-Feb-16 & 132.104 & 162.291 & -0.15 & 162.203 & -0.234 & 163.156 & -0.218 & 162.869 & -0.310 & 163.369 & -0.236 & 163.351 & -0.278 & 163.279 & -0.249 & 163.301 & -0.219 & 162.572 & -0.219 & 162.642 & -0.178 \\
\hline 25-Feb-16 & 131.112 & 162.252 & -0.189 & 162.168 & -0.269 & 163.114 & -0.26 & 162.794 & -0.385 & 163.339 & -0.266 & 163.311 & -0.318 & 163.247 & -0.281 & 163.262 & -0.258 & 162.526 & -0.265 & 162.582 & -0.238 \\
\hline 15-Mar-16 & 131.713 & 162.240 & -0.201 & 162.158 & -0.279 & 163.103 & -0.271 & 162.779 & -0.400 & 163.330 & -0.275 & 163.300 & -0.329 & 163.235 & -0.293 & 163.253 & -0.267 & 162.516 & -0.275 & 162.570 & -0.250 \\
\hline 25-Mar-16 & 125.927 & 162.234 & -0.207 & 162.149 & -0.288 & 163.092 & -0.282 & 162.765 & -0.414 & 163.300 & -0.305 & 163.267 & -0.362 & 163.197 & -0.331 & 163.219 & -0.301 & 162.503 & -0.288 & 162.554 & -0.266 \\
\hline 15-Apr-16 & 130.973 & 162.222 & -0.219 & 162.134 & -0.303 & 163.080 & -0.294 & 162.753 & -0.426 & 163.280 & -0.325 & 163.247 & -0.382 & 163.174 & -0.354 & 163.200 & -0.320 & 162.488 & -0.303 & 162.534 & -0.286 \\
\hline 16-May-16 & 119.831 & 162.218 & -0.223 & 162.131 & -0.306 & 163.067 & -0.307 & 162.740 & -0.439 & 163.268 & -0.337 & 163.235 & -0.394 & 163.162 & -0.366 & 163.196 & -0.324 & 162.476 & -0.315 & 162.524 & -0.296 \\
\hline 14-Jun-16 & 120.005 & 162.210 & -0.231 & 162.121 & -0.316 & 163.050 & -0.324 & 162.727 & -0.452 & 163.251 & -0.354 & 163.221 & -0.408 & 163.137 & -0.391 & 163.180 & -0.340 & 162.465 & -0.326 & 162.514 & -0.306 \\
\hline 14-Jul-16 & 115.241 & 162.204 & -0.237 & 162.113 & -0.324 & 163.042 & -0.332 & 162.715 & -0.464 & 163.238 & -0.367 & 163.204 & -0.425 & 163.120 & -0.408 & 163.170 & -0.350 & 162.450 & -0.341 & 162.499 & -0.321 \\
\hline 15-Aug-16 & 112.415 & 162.200 & -0.241 & 162.109 & -0.328 & 163.030 & -0.344 & 162.708 & -0.471 & 163.227 & -0.378 & 163.197 & -0.432 & 163.113 & -0.415 & 163.158 & -0.362 & 162.450 & -0.341 & 162.491 & -0.329 \\
\hline & & & CSU1< & CSD1 & & & CSU2 $<$ & CSD2 & & & CSU3< & CSD3 & & & CSU4> & CSD4 & & & CSU5> & $>$ CSD5 & \\
\hline
\end{tabular}

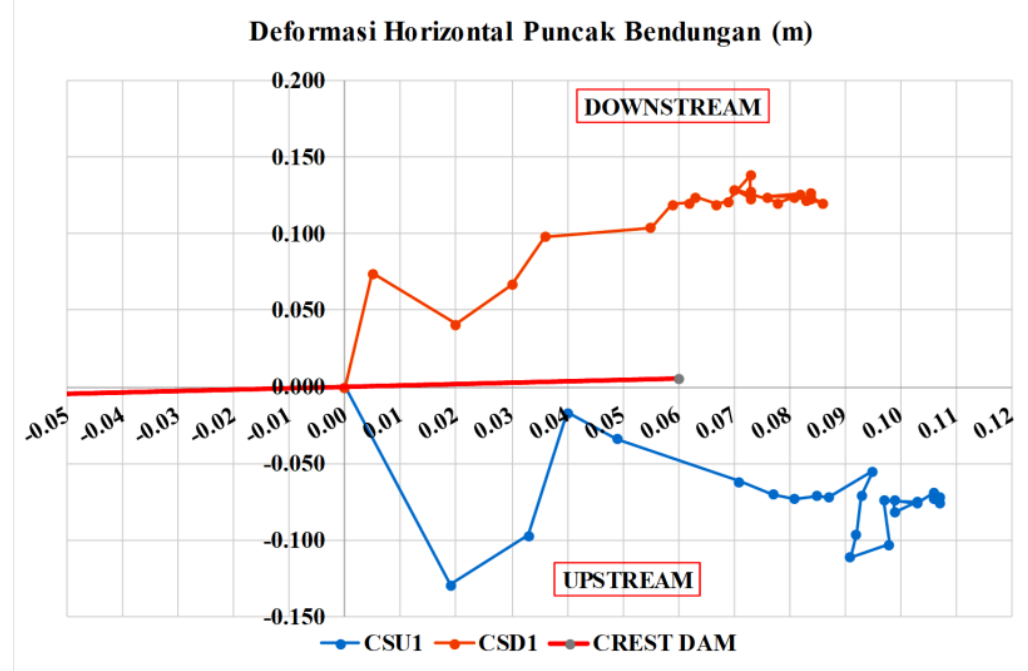

Gambar 9. Grafik deformasi horizontal pada puncak bendungan berdasarkan patok geser CSU1 dan CSD1

Tabel 4. Nilai deformasi horizontal patok CSU1 dan CSD1

\begin{tabular}{|c|c|c|c|c|c|}
\hline Tanggal & CSU1 & & CSD1 & & Deformasi \\
\hline Pembacaa & $\Delta X(\mathrm{~m})$ & $\Delta \mathrm{Y}(\mathrm{m})$ & $\Delta \mathrm{X}(\mathrm{m})$ & $\Delta \mathrm{Y}(\mathrm{m})$ & Total (m) \\
\hline 21-Nov-15 & 0.000 & 0.000 & 0.000 & 0.000 & 0.000 \\
\hline 5-Jan-16 & 0.019 & -0.129 & 0.005 & 0.074 & -0.203 \\
\hline 15-Jan-16 & 0.033 & -0.097 & 0.020 & 0.041 & -0.138 \\
\hline 25-Jan-16 & 0.040 & -0.017 & 0.030 & 0.067 & -0.084 \\
\hline 2-Feb-16 & 0.049 & -0.034 & 0.036 & 0.098 & -0.132 \\
\hline 15 -Feb-16 & 0.071 & -0.062 & 0.055 & 0.104 & -0.166 \\
\hline 25 -Feb- 16 & 0.077 & -0.070 & 0.059 & 0.119 & -0.189 \\
\hline
\end{tabular}

Gambar 10 menunjukkan deformasi horizontal pada puncak bendungan pada abutmen kiri berdasarkan patok CSU2 (hulu) dan CSD2 (hilir). Pergerakan yang terjadi adalah puncak bendungan bagian hulu bergerak ke hulu dan mengarah ke kanan sedangkan pergerakan puncak bendungan bagian hilir bergerak ke hilir dan kekanan (menuju lembah). Deformasi yang terjadi sebesar $0,101 \mathrm{~m}$ pada tanggal 5 Januari 2016 dan bertambah menjadi $0,202 \mathrm{~m}$ pada tanggal 25 Februari 2016. Nilai deformasi patok CSU2 dan CSD2 dapat dilihat pada Tabel 5.
Gambar 11 menunjukkan deformasi horizontal pada puncak bendungan bagian tengah berdasarkan patok CSU3 (hulu) dan CSD3 (hilir). Pergerakan yang terjadi adalah puncak bendungan bagian hulu bergerak kehulu dan mengarah ke kanan sedangkan pergerakan puncak bendungan bagian hilir bergerak ke hilir dan kekiri. Deformasi yang terjadi sebesar 0,037 $\mathrm{m}$ pada tanggal 5 Januari 2016 dan bertambah menjadi 0,162 m pada tanggal 25 Februari 2016. Nilai deformasi patok CSU3 dan CSD3 dapat dilihat pada Tabel 6. 


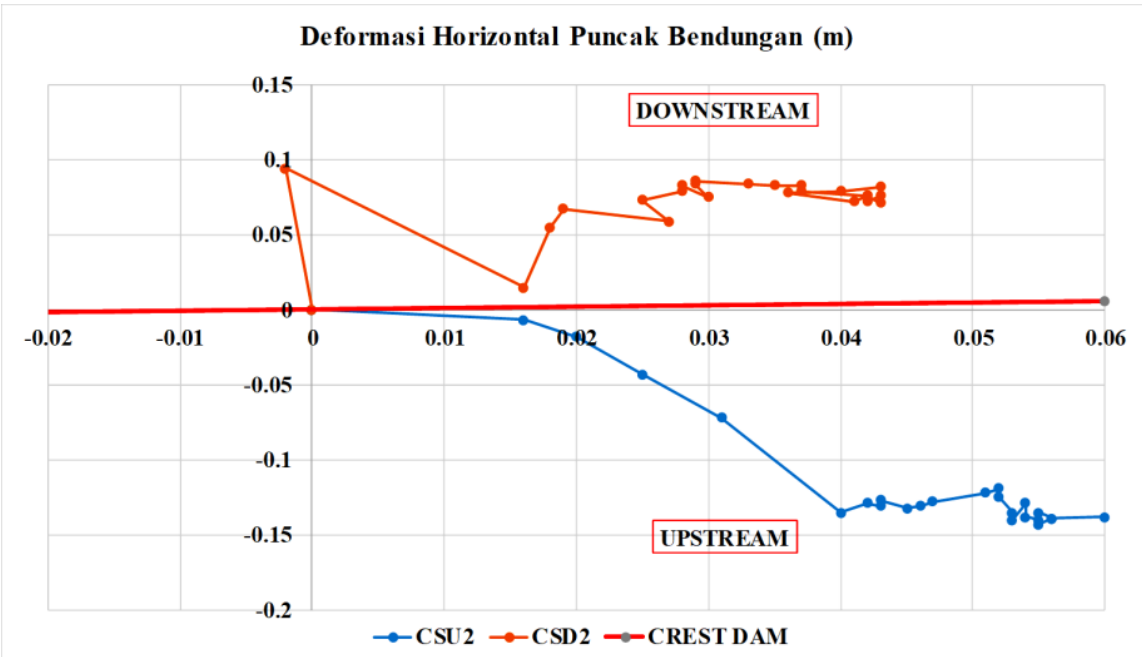

Gambar 10. Grafik deformasi horizontal pada puncak bendungan berdasarkan patok geser CSU2 dan CSD2

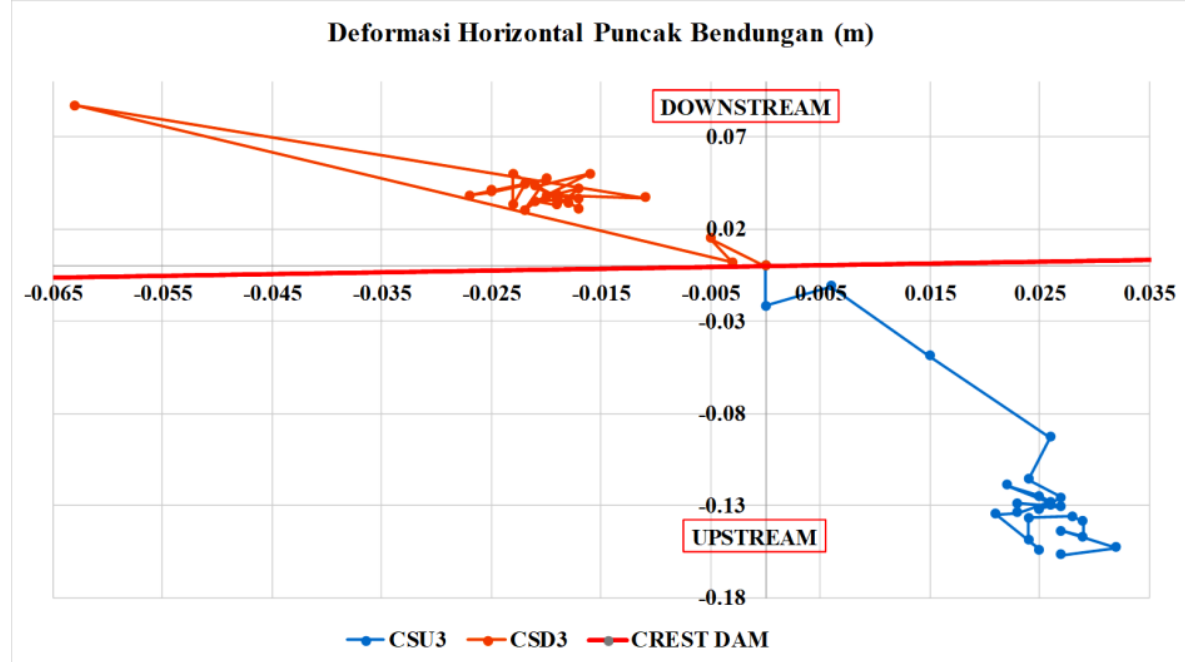

Gambar 11. Grafik deformasi horizontal pada puncak bendungan berdasarkan patok geser CSU3 dan CSD3.

Tabel 5. Nilai deformasi horizontal patok CSU2 dan CSD2

\begin{tabular}{|c|c|c|c|c|c|}
\hline Tanggal & CSU2 & & CSD2 & & Deformasi \\
\hline Pembacaa & $\Delta \mathrm{X}(\mathrm{m})$ & $\Delta \mathrm{Y}(\mathrm{m})$ & $\Delta \mathrm{X}(\mathrm{m})$ & $\Delta \mathrm{Y}(\mathrm{m})$ & Total (m) \\
\hline 21-Nov-15 & 0.000 & 0.000 & 0.000 & 0.000 & 0.000 \\
\hline 5-Jan-16 & 0.016 & -0.007 & -0.002 & 0.094 & -0.101 \\
\hline 15-Jan-16 & 0.020 & -0.018 & 0.016 & 0.015 & -0.033 \\
\hline 25-Jan-16 & 0.025 & -0.043 & 0.018 & 0.055 & -0.098 \\
\hline 2-Feb-16 & 0.031 & -0.072 & 0.019 & 0.067 & -0.139 \\
\hline 15 -Feb-16 & 0.040 & -0.135 & 0.027 & 0.059 & -0.194 \\
\hline 25 -Feb- 16 & 0.042 & -0.129 & 0.025 & 0.073 & -0.202 \\
\hline
\end{tabular}

Gambar 12 menunjukkan deformasi horizontal pada puncak bendungan bagian abutmen kanan berdasarkan patok CSU4 (hulu) dan CSD4 (hilir). Pergerakan yang terjadi adalah puncak bendungan bagian hulu bergerak kehulu dan mengarah ke kiri sedangkan pergerakan
Tabel 6. Nilai deformasi horizontal patok CSU3 dan CSD3

\begin{tabular}{|c|c|c|c|c|c|}
\hline Tanggal & CSU3 & & CSD3 & & Deformasi \\
\hline Pembacaan & $\Delta \mathrm{X}(\mathrm{m})$ & $\Delta \mathrm{Y}(\mathrm{m})$ & $\Delta \mathrm{X}(\mathrm{m})$ & $\Delta \mathrm{Y}(\mathrm{m})$ & Total (m) \\
\hline 21-Nov-15 & 0.000 & 0.000 & 0.000 & 0.000 & 0.000 \\
\hline 5-Jan-16 & 0.000 & -0.022 & -0.005 & 0.015 & -0.037 \\
\hline 15-Jan-16 & 0.006 & -0.011 & -0.003 & 0.002 & -0.013 \\
\hline 25-Jan-16 & 0.015 & -0.049 & -0.063 & 0.087 & -0.136 \\
\hline 2-Feb-16 & 0.026 & -0.093 & -0.011 & 0.037 & -0.13 \\
\hline 15 -Feb- 16 & 0.024 & -0.116 & -0.019 & 0.038 & -0.154 \\
\hline 25 -Feb- 16 & 0.027 & -0.126 & -0.017 & 0.036 & -0.162 \\
\hline
\end{tabular}

puncak bendungan bagian hilir bergerak ke hilir dan kekiri. Deformasi yang terjadi sebesar 0,016 m pada tanggal 5 Januari 2016 dan bertambah menjadi 0,202 m pada tanggal 25 Februari 2016. Nilai deformasi patok CSU4 dan CSD4 dapat dilihat pada Tabel 7. 
Gambar 13 menunjukkan deformasi horizontal pada puncak bendungan bagian abutmen kanan berdasarkan patok CSU5 (hulu) dan CSD5 (hilir). Pergerakan yang terjadi adalah puncak bendungan bagian hulu bergerak kehulu dan mengarah ke kiri sedangkan pergerakan puncak bendungan bagian hilir bergerak ke hilir dan kekiri. Deformasi yang terjadi sebesar 0,027 $\mathrm{m}$ pada tanggal 5 Januari 2016 dan bertambah menjadi $0,236 \mathrm{~m}$ pada tanggal 25 Februari 2016. Nilai deformasi patok CSU5 dan CSD5 dapat dilihat pada Tabel 8.

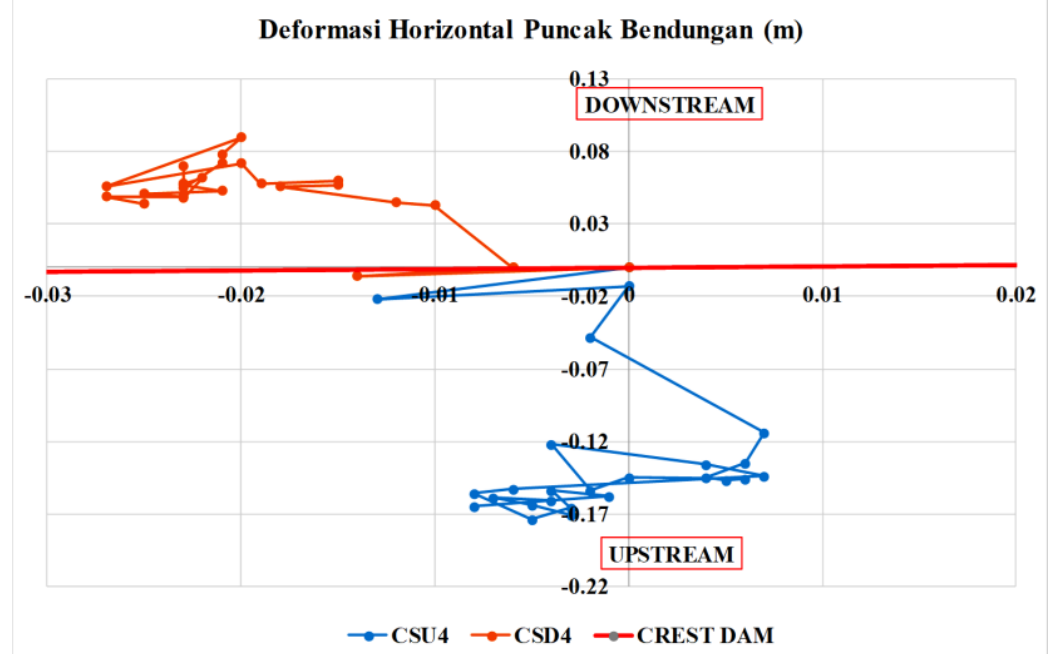

Gambar 12. Grafik deformasi horizontal pada puncak bendungan berdasarkan patok geser CSU4 dan CSD4

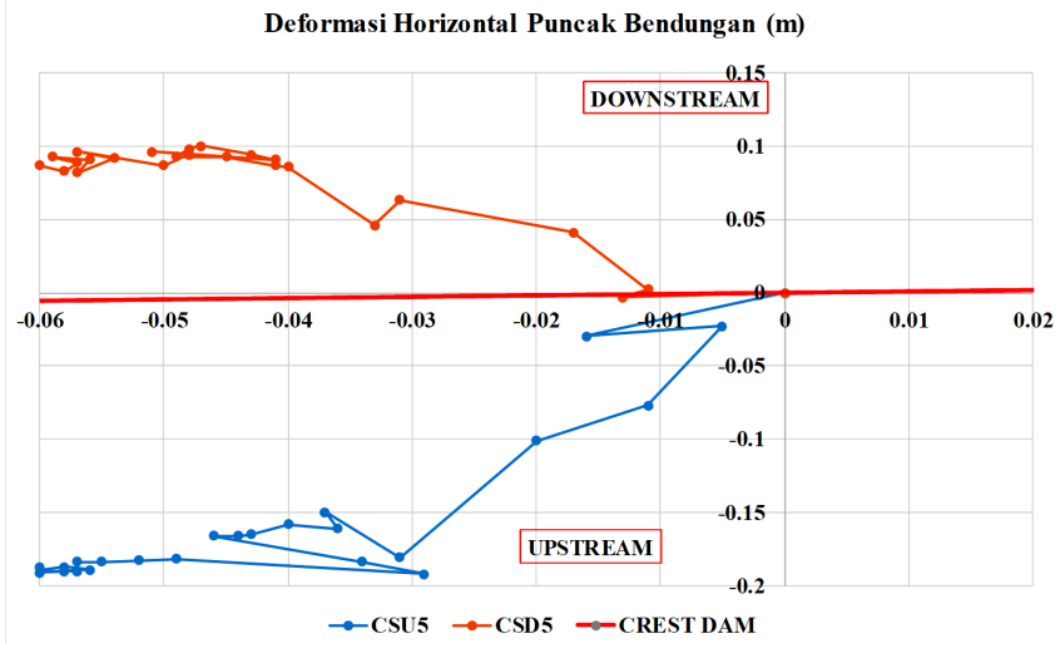

Gambar 13. Grafik deformasi horizontal pada puncak bendungan berdasarkan patok geser CSU5 dan CSD5.

Tabel 7. Nilai deformasi horizontal patok CSU4 dan

\begin{tabular}{|c|c|c|c|c|c|}
\hline CSD4 & CSU4 & \multicolumn{3}{|c|}{ CSD4 } & Deformasi \\
\hline Pembacaan & $\Delta \mathrm{X}(\mathrm{m})$ & $\Delta \mathrm{Y}(\mathrm{m})$ & $\Delta \mathrm{X}(\mathrm{m})$ & $\Delta \mathrm{Y}(\mathrm{m})$ & Total (m) \\
\hline 21-Nov-15 & 0.000 & 0.000 & 0.000 & 0.000 & 0.000 \\
\hline 5-Jan-16 & -0.013 & -0.022 & -0.014 & -0.006 & -0.016 \\
\hline 15-Jan-16 & 0.000 & -0.013 & -0.006 & 0.000 & -0.013 \\
\hline 25-Jan-16 & -0.002 & -0.048 & -0.010 & 0.043 & -0.091 \\
\hline 2-Feb-16 & 0.007 & -0.114 & -0.012 & 0.045 & -0.159 \\
\hline 15-Feb-16 & 0.006 & -0.135 & -0.018 & 0.056 & -0.191 \\
\hline 25-Feb-16 & 0.004 & -0.145 & -0.015 & 0.057 & -0.202 \\
\hline
\end{tabular}

Tabel 8. Nilai deformasi horizontal patok CSU5 dan CSD5

\begin{tabular}{rrrrrr}
\hline Tanggal & CSU5 & \multicolumn{3}{c}{ CSD5 } & \multicolumn{2}{c}{ Deformasi } \\
Pembacaa & $\Delta \mathrm{X}(\mathrm{m})$ & $\Delta \mathrm{Y}(\mathrm{m})$ & $\Delta \mathrm{X}(\mathrm{m})$ & $\Delta \mathrm{Y}(\mathrm{m})$ & Total $(\mathrm{m})$ \\
\hline 21-Nov-15 & 0.000 & 0.000 & 0.000 & 0.000 & 0.000 \\
5-Jan-16 & -0.016 & -0.030 & -0.013 & -0.003 & -0.027 \\
15-Jan-16 & -0.005 & -0.023 & -0.011 & 0.002 & -0.025 \\
25-Jan-16 & -0.011 & -0.077 & -0.017 & 0.041 & -0.118 \\
2-Feb-16 & -0.020 & -0.101 & -0.031 & 0.063 & -0.164 \\
15-Feb-16 & -0.031 & -0.181 & -0.033 & 0.046 & -0.227 \\
25-Feb-16 & -0.037 & -0.150 & -0.040 & 0.086 & -0.236 \\
\hline
\end{tabular}


Hubungan muka air waduk saat pengisian awal terhadap deformasi horizontal arah Y (hulu hilir) dapat dilihat pada Gambar 14, dimana patok geser CSU3 bergerak ke hulu sedangkan patok geser CSD3 bergerak kehilir. Deformasi horizontal arah hulu-hilir dimulai sejak pengisian awal waduk dan terpengaruh oleh ketinggian muka air waduk.

Arah/pola deformasi horizontal masingmasing patok geser dapat dilihat pada Gambar 15. Terdapat arah pergerakan yang tidak selaras yang ditunjukkan pada patok geser CSD3 pada puncak bendungan bagian hilir. Verifikasi arah

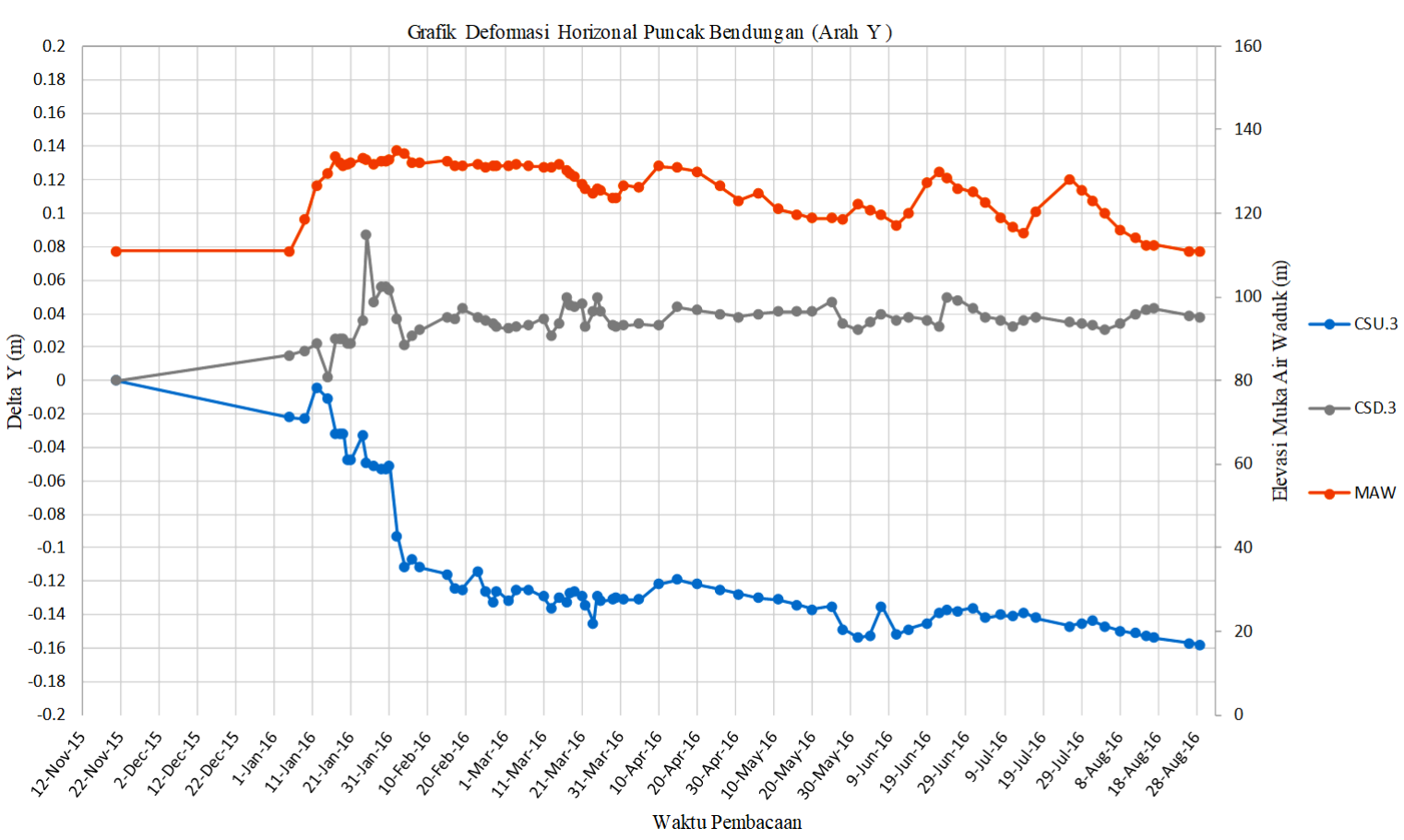

Gambar 14. Grafik hubungan muka air waduk dan deformasi horizontal arah Y (hulu-hilir) pada patok CSU3 dan CSD3

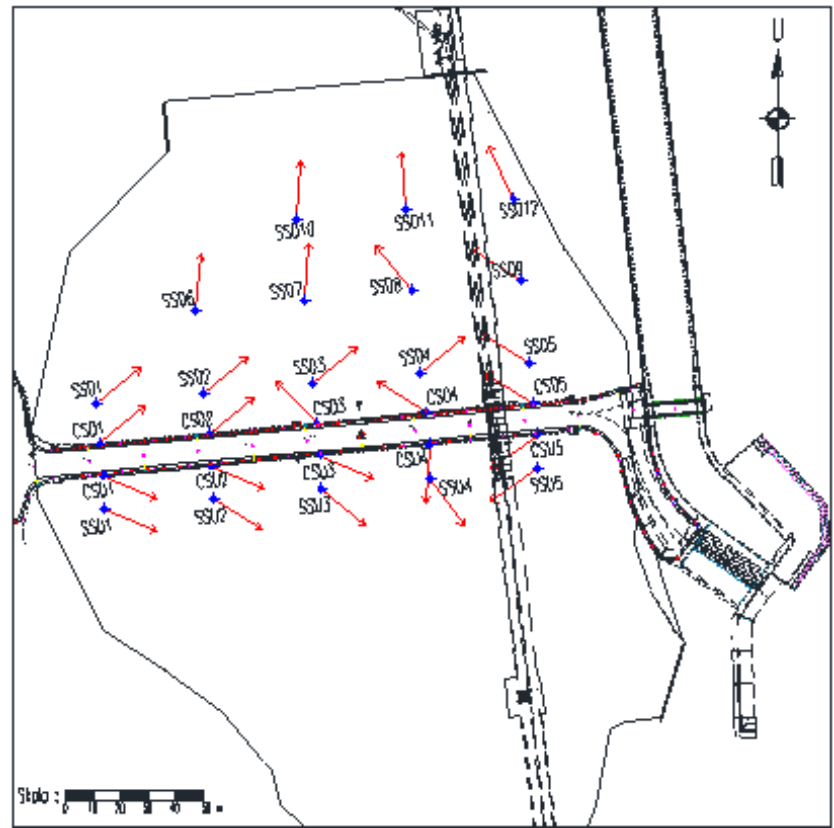

Gambar 15. Pola deformasi horizontal pada tubuh bendungan berdasarkan pembacaan instrumentasi patok geser. 
pergerakan tersebut menggunakan data inclinometer yang terpasang pada tubuh bendungan. Data inclinometer yang dapat digunakan adalah inclinometer yang terpasang paling dekat dengan posisi patok geser CSD3 yaitu inclinometer dengan kode INC-sta.5. Gambar 16 menunjukkan arah deformasi horizontal pada inclinometer INC-sta.5 dengan arah Y (hulu-hilir). Gambar 17 menunjukkan arah deformasi horizontal pada inclinometer INC-sta.5 dengan arah $\mathrm{X}$ (abutmen kananabutmen kiri).

Gambar 16 menunjukkan pergerakan puncak bendungan berdasarkan pembacaan inclinometer INC.5 dimana puncak bendungan bergerak mengarah ke hilir sebesar $4,45 \mathrm{~cm}$ sesuai pembacaan tanggal 12 Februari 2016 dan bertambah menjadi 4,93 $\mathrm{cm}$ pada tanggal 19 Agustus 2016 pada plate kedalaman 0,5 m. Arah tersebut sesuai dengan hasil pembacaan patok geser CSD3 yaitu puncak bendungan mengarah ke hilir dengan nilai sebesar $3,8 \mathrm{~cm}$ pada tanggal 15 Februari 2016 dan bertambah menjadi $4,2 \mathrm{~cm}$ pada tanggal 15 Agustus 2016. Hal ini menunjukkan bahwa pengisian awal waduk mempengaruhi nilai deformasi horizontal pada puncak bendungan.

Gambar 17 menunjukkan pergerakan puncak bendungan berdasarkan pembacaan inclinometer INC sta.5 dimana puncak bendungan bergerak ke arah abutmen kanan. Hasil yang berbeda ditunjukkan pada pembacaan patok geser CSD3 dimana puncak bendungan justru bergerak ke kiri seperti terlihat pada Gambar 11.

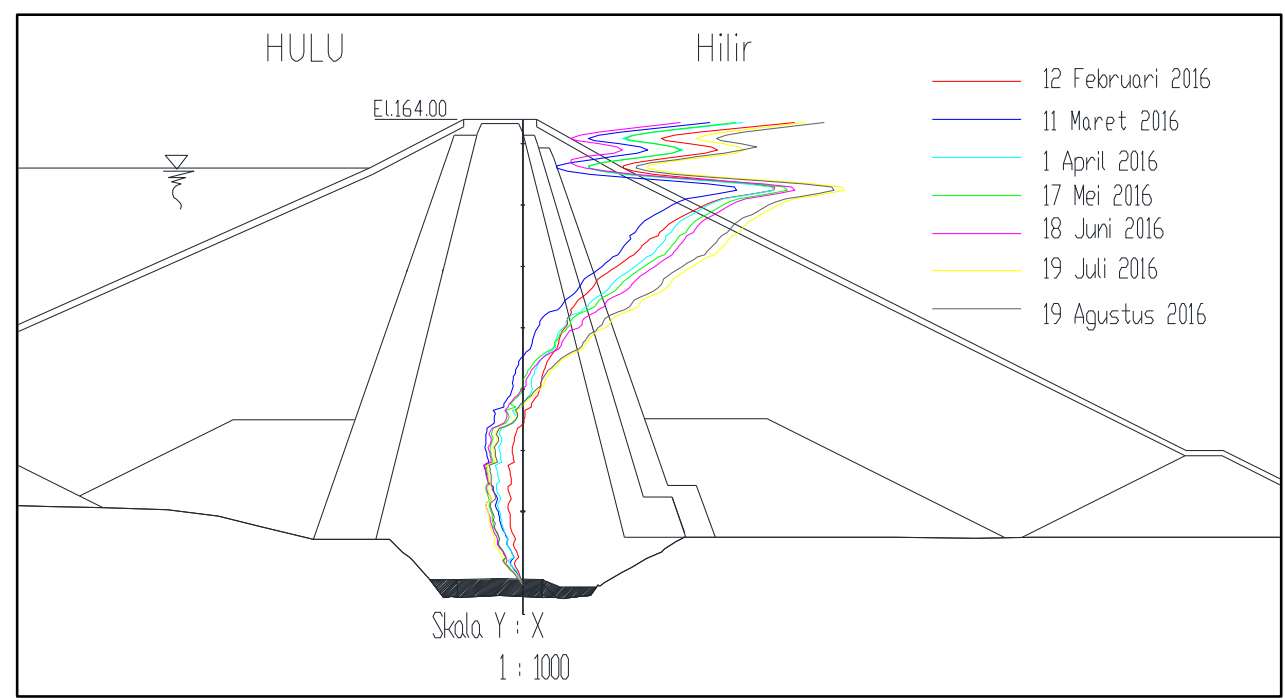

Gambar 16. Potongan melintang sta. 5 dengan pergerakan inclinometer axis A (hulu-hilir).

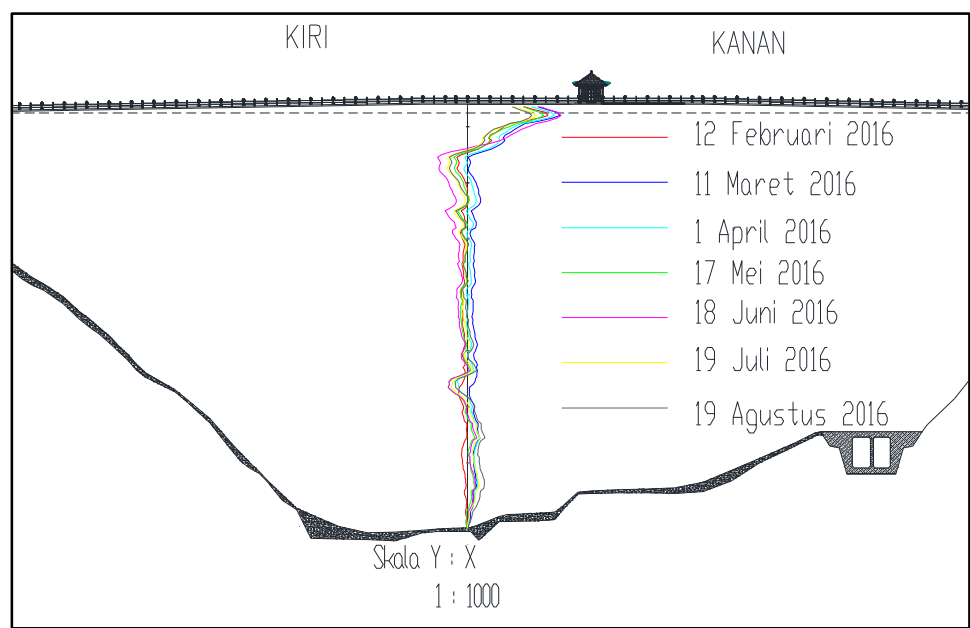

Gambar 17. Potongan memanjang bendungan dengan pergerakan inclinometer axis B (abutment kanan-kiri). 


\section{PEMBAHASAN}

Dari hasil analisis menunjukkan bahwa deformasi vertikal / settlement pada puncak bendungan terjadi sejak pengisian awal waduk, dan nilainya semakin meningkat seiring dengan kenaikan muka air waduk. Terdapat perbedaan nilai deformasi vertikal antara puncak hulu dan hilir. Nilai deformasi vertikal pada puncak hilir lebih besar dibandingkan dengan nilai deformasi vertikal pada puncak hulu ditunjukkan pada daerah abutmen kiri yaitu patok 1, 2, dan 3, sedangkan pada daerah abutmen kanan yaitu patok 4 dan 5 menunjukkan nilai deformasi vertikal pada puncak hulu lebih besar dari puncak hilir. Deformasi horizontal arah hulu-hilir menunjukkan arah pergerakan pada daerah lereng hulu bergerak ke hulu, sedangkan daerah hilir bergerak ke hilir pada saat pengisian awal waduk. Deformasi horizontal arah memanjang/ longitudinal (abutmen kanan dan kiri), secara umum arah pergerakan menuju lembah terdalam. Bagian abutmen kanan bendungan bergerak ke kiri, sedangkan bagian kiri abutmen bergerak kekanan. Deformasi yang terjadi pada tubuh bendungan memiliki hubungan atau berkorelasi terhadap peningkatan elevasi muka air waduk (Shi dkk., 2015; Yigit dkk., 2016; Michalis dkk., 2016; De Lacy dkk., 2017; Ventrella dkk., 2019; Konakoglu dkk., 2020).

USBR (2011) menyatakan bahwa pola umum deformasi pada bagian hulu adalah kebawah dan ke hulu, sedangkan pada bagian hilir bergerak ke bawah dan ke hilir. Di sisi lain puncak bendungan bergerak ke bawah dan kehulu selama pengisian pertama waduk dan bergerak turun ke arah hilir saat air waduk mulai melewati tubuh bendungan. Pergerakan permukaan pada daerah abutmen bergerak horizontal menuju lembah terdalam.

Rekahan pada puncak Bendungan Titab bagian hulu terjadi sebagai akibat bendungan tersebut mendapat beban pada saat pengisian air waduk. Hal tersebut juga terjadi pada beberapa bendungan lain. Selama pengisian awal waduk terjadi peningkatan tekanan pori pada zona inti disisi hulu, penurunan/settlement yang tidak sama terjadi antara zona inti dan zona filter (Akhtarpour dan Salari, 2021). Peningkatan tekanan air terjadi pada pengisian awal waduk dapat mengurangi tegangan efektif material tanah dan jika mencapai nilai yang cukup rendah akan menimbulkan rekahan (Haeri dan Faghihi, 2008). Kestabilan lereng erat kaitannya dengan fluktuasi muka air waduk, berakibat pada berkurangnya kuat geser tanah dan meningkatnya tekanan hidrodinamik dan statis tanah sehingga rawan terhadap deformasi dan ketidakstabilan lereng (Wang dkk., 2019). Deformasi pada tubuh bendungan dan pondasi terbukti berkorelasi pada saat pengisian awal waduk (Wang dkk., 2020).

\section{KESIMPULAN DAN SARAN \\ Kesimpulan}

Rekahan pada puncak Bendungan Titab berdasarkan hasil analisis pembacaan instrumentasi patok geser disebabkan karena perbedaan nilai deformasi vertikal/settlement antara hulu dan hilir, dan arah pergerakan deformasi horizontal yang terjadi pada puncak bendungan yaitu puncak hulu bergerak ke hulu sedangkan puncak hilir bergerak kehilir dengan nilai berkisar antara $15-20 \mathrm{~cm}$. Deformasi yang terjadi pada tubuh Bendungan Titab dimulai sejak pengisian awal waduk dan terpengaruh oleh peningkatan elevasi muka air waduk.

\section{Saran}

Terhadap rekahan yang sudah terjadi agar dilakukan tindakan penutupan/mengisi kembali material timbunan untuk menghindari masuknya air hujan. Agar melakukan pemantauan yang intensif dan analisis lebih lanjut guna mendapatkan informasi lebih detail terhadap penyebab rekahan.

\section{UCAPAN TERIMA KASIH}

Tertuju kepada Kementerian Pekerjaan Umum dan Perumahan Rakyat melalui BPSDM Kementerian PUPR yang telah memfasilitasi penelitian dan program beasiswa S2 Magister Super Spesialis, kepada semua staf dan dosen Departemen Teknik Sipil Fakultas Teknik Universitas Diponegoro, dan kepada Balai Wilayah Sungai Bali-Penida yang telah memfasilitasi data pada penelitian ini.

\section{DAFTAR PUSAKA}

Anggara, I.P.H., Sangkawati, S., Putranto, T.T., 2021. Analisis Potensi Erosi Buluh Akibat Pengaruh Mata Air Pada Bendungan Titab. (Publikasi dalam proses).

Akhtarpour, A. dan Salari, M., 2021. The deformation mechanism of a high rockfill dam during the construction and first impounding. Scientia Iranica. https://doi.org/10.24200/sci.2018.20778

BWS Bali-Penida, 2015. Laporan Supervisi 
Bendungan Titab. PT. Indra Karya (Persero). Bali.

Central Water Commission, 2018. Guidelines for Preparing Operation and Maintenance Manual for Dams. Ministry of Water Resources, Development \& Ganga Rejuvenation; Government of India.

De Lacy, M.C., Ramos, M.I., Gil, A.J., Franco, Ó.D., Herrera, A.M., Avilés, M., Domínguez, A., Chica, J.C., 2017. Monitoring of vertical deformations by means high-precision geodetic levelling. Test case: The Arenoso dam (South of Spain). Journal of Applied Geodesy. https://doi.org/10.1515/jag-2016-0034.

Haeri, S.M. dan Faghihi, D., 2008. Predicting Hydraulic Fracturing in Hyttejuvet Dam. Sixth International Conference on Case Histories in Geotechnical Engineering, 011.

Indrawan, D., Tanjung, M.I., Setyawan, H.E., Sadikin, N., 2015. Analisis Statik dan DInamik Retakan Memanjang di Puncak Bendungan Sutami. Jurnal Teknik Hidraulik, 6(1), hal.77-90. DOI: https://doi.org/10.32679/jth.v6i1.514

Konakoglu, B., Cakir, L., Yilmaz, V., 2020. Monitoring the deformation of a concrete dam: a case study on the Deriner Dam, Artvin, Turkey. Geomatics, Natural Hazards and Risk, 11(1), hal.160-177. https://doi.org/10.1080/19475705.2020.171 4755.

Michalis, P., Pytharouli, S. I., Raftopoulos, S., 2016. Long-term Deformation Patterns of Earth-fill Dams based on Geodetic Monitoring Data: the Pournari I Dam Case Study. Proceeding of 3rd Joint International Symposium on Deformation Monitoring, hal.1-5.

Purwoko, F., Sudarsono, B., Amarrohman, F., 2017. Pemantauan Deformasi Bendungan Jatibarang Menggunakan Scientific Software Gamit 10.6 Dengan Titik Ikat Igs Dan Cors Csem Tahun 2016. Jurnal Geodesi Undip, 6(2), 37-45.

Putra, T.G.S., Aribudiman, I.N., Juliawan, G.R., 2019. Analisis Stabilitas Lereng Pada Bendungan Titab. Jurnal Ilmiah Teknik Sipil, 20(1), hal.1689-1699.

Rashidi, M. dan Haeri, S.M., 2017. Evaluation of behaviors of earth and rockfill dams during construction and initial impounding using instrumentation data and numerical modeling. Journal of Rock Mechanics and Geotechnical Engineering, 9(4), hal.709725.

https://doi.org/10.1016/j.jrmge.2016.12.00 3.

Shi, Z.M., Wang, Y.Q., Peng, M., Guan, S.G., Chen, J.F., 2015. Landslide dam deformation analysis under aftershocks using large-scale shaking table tests measured by videogrammetric technique. Engineering Geology. https://doi.org/10.1016/j.enggeo.2014.09.0 08.

USBR (U.S. Department of the Interior Bureau of Reclamation), 2011. Chapter 9: Static Deformation Analysis Phase 4 (Final). Reclamation Managing Water in the West. U.S. Department of the Interior Bureau of Reclamation, Power Resources Office.

Ventrella, C., Pelecanos, L., Skarlatos, D., Pantazis, G., 2019. Statistical analysis of long-term earth dam settlements. Proceedings of the XVII European Conference on Soil Mechanics and Geotechnical Engineering, https://doi.org/10.32075/17ECSMGE2019-0739.

Wang, J., 2007. Hydraulic fracturing of rock-fill dam. The International Journal of Multiphysics, 1(2), hal.199-219.

Wang, H., Sun, Y., Tan, Y., Sui, T., Sun, G., 2019. Deformation characteristics and stability evolution behavior of Woshaxi landslide during the initial impoundment period of the Three Gorges reservoir. In Environmental Earth Sciences (Vol. 78, Issue 20). https://doi.org/10.1007/s12665019-8592-6.

Wang, X.W., Zhuang, W.Y., Liu, Y.R., Xue, L. J., Cheng, L., Yang, Q., 2020. Study on the deformation mechanism of abutment slope and its influence on the dam during the impoundment of high arch dam. IOP Conference Series: Earth and Environmental Science, 570(6). https://doi.org/10.1088/17551315/570/6/062011.

Won, M. S. dan Kim, Y. S. (2008). A case study on the post-construction deformation of concrete face rockfill dams. Canadian Geotechnical Journal, 45(6), 845-852. https://doi.org/10.1139/T08-020. 
Yigit, C.O., Alcay, S., Ceylan, A., 2016. Displacement response of a concrete arch dam to seasonal temperature fluctuations and reservoir level rise during the first filling period: evidence from geodetic data. Geomatics, Natural Hazards and Risk. DOI:

https://doi.org/10.1080/19475705.2015.104 7902.

Zhou, X., Chi, S., Wang, M., Jia, Y., 2020. Study on wetting deformation characteristics of coarse granular materials and its simulation in core-wall rockfill dams. International Journal for Numerical and Analytical Methods in Geomechanics. DOI: https://doi.org/10.1002/nag.3042. 